\title{
Alienated and politicized? Young planners' confrontation with entrepreneurial and authoritarian state intervention in urban development in Turkey
}

\author{
Mehmet Penpecioğlu ${ }^{\mathrm{a}, \mathrm{c}}$ and Tuna Taşan-Kok ${ }^{\mathrm{b}, \mathrm{c}}$ \\ ${ }^{\mathrm{a}}$ Faculty of Architecture, Department of City and Regional Planning, İzmir Institute of Technology, İzmir, \\ Turkey; ${ }^{b}$ Faculty of Social and Behavioural Sciences, Department of Human Geography, Planning and \\ International Development, University of Amsterdam, Amsterdam, The Netherlands; ${ }^{\text {CFaculty }}$ of Architecture \\ and the Built Environment, OTB Research for the Built Environment, TUDelft, Delft, The Netherlands
}

\begin{abstract}
Planning in Turkey is dominated by powerful market interests and authoritarian state regulation, resulting in a conflictual socio-political environment. Caught in the crossfire between interventionist urban policies and a planning education system that is oriented towards the public good, planners have come to feel alienated from their work. This paper considers how young planners respond to these challenges, drawing upon questionnaires and semi-structured in-depth interviews with planners with fewer than 10 years of experience. Their confrontation with entrepreneurial and authoritarian state interventions in urban development alienates them from their ideals, leading them to explore new ways of dealing with increasing political authority and economic neoliberalism. The participants of the study came up with a number of diverse responses related to this process. Disappointed with the practice of their profession 'lost planners' begin searching for alternative pathways outside their practice towards a more meaningful society. In contrast, 'profiteer planners' focus on getting more business and play a conformist and opportunistic role in the existing planning practice; while 'struggling planners' develop alternative ways to pursue the public good by participating in urban movements. In short, they cope with alienation through politicization, solidarity and the identification of new means of engaging with society.
\end{abstract}

\section{ARTICLE HISTORY}

Received 15 July 2015

Accepted 3 December 2015

\section{KEYWORDS}

Young planners; state intervention in urban development; Turkish urban planning practice; alienation; politicization

\section{Introduction}

Planning in Turkey has always been a contentious profession, rife with contradictions, conflicts and power struggles; while planning education in Turkish universities, like elsewhere, follows an academic curriculum that is based on a set of principles that define ethics and values in planning practice targeting the public good. Planning doctrine has traditionally been implemented through a system of top-down governance, with political authorities enforcing regulations according to a strictly bureaucratic tradition, but needing

CONTACT Mehmet Penpecioğlu mpembeci@gmail.com

This article was originally published with errors. This version has been corrected. Please see Corrigendum (http://dx.doi. org/10.1080/09654313.2016.1176766)

(C) 2016 Informa UK Limited, trading as Taylor \& Francis Group 
the flexibility, informality and exceptionality to serve private interests. As a result, planning practice in Turkey operates in a grey area that is marked by contradictions: entrepreneurialism and market domination; increasing state intervention; and, in response, bottom-up urban movements. Although the state's top-down interference in urban development has always been prominent, the tradition has become more authoritarian over the last decade under the leadership of a conservative centre-right government that has, over the last decade, come to be supported by the lower middle classes, by disaffected segments of the working classes and by the 'new liberal intellectuals' (Eraydin $\&$ Tasan-Kok, 2013). As a result, young urban planners find themselves in a contradictory socio-political environment in which the boundaries between legal and illegal are continuously shifting, where private interests override the public good, and where opposition is almost illegal.

Since the beginning of the 1980s, Turkey's top-down and managerial system of urban government has been replaced by an entrepreneurial governance model that is based on urban land and property speculation, and opportunity-led development (Tasan-Kok, 2004). This shift gained momentum under the Justice and Development Party (AKP) government, whose economic policies pursued strong economic growth aimed at legitimizing socio-political and institutional change, based on conservative value systems and strong religious rhetoric (Eraydin \& Tasan-Kok, 2013). Instead of relying on market dynamics, the state adopted a more active role, facilitating urban regeneration and huge investments with mega projects; assigning special rights and responsibilities to central state departments; and imposing new regulations, laws and decrees (Balaban, 2012; Eraydin, 2012; Penpecioglu, 2011). These authoritarian state-regulated conditions are characteristic of the hybrid neoliberal regime in Turkey, which cherishes entrepreneurialism from the scale of the individual to the state. Within this context, and with very little to be gained from opposing the entrepreneurial top-down interventions, Turkish planners become subjected to pressures and start to feel disappointed and hopeless. In this article, we argue that such disappointment with the practice alienates young planners from their profession, and it is our intention to shed light on the alternative used by young planners to overcome this feeling, and to navigate between the diverse pressures created by the practice. Although the research draws upon Turkish planners, based on the growing body of international research into the gap between planning education and practice, the authors conclude that these feelings of alienation from the planning profession are not only a Turkish phenomenon.

Almost everywhere in the world planners feel such cross pressure as a result of the 'conflicting values held by educators and the professional community, influenced by communicative planning theory on the one hand, and politicians and administrators promoting new public management on the other' (Sager, 2009, p. 65). Despite this entrepreneurial shift, the prevailing view in planning theory emphasizes the importance of communication and participation in the decision-making process (Forester, 1989; Healey, 1996). For planning communities and educators, collaborative and strategic approaches are considered pioneering values (Albrechts, 2004; Sager, 2005), and as can be understood from recent successes in cases related to planning practice, planners are learning how to listen in situations of disagreement (Sherman, 2013). By developing communication and mediation skills, they see that they can enhance their problem-solving capacity under conflictual conditions (Blechman, 2013). The crucial goal in practice is to create a platform 
where different parties can come together and learn from each other with empathy, which in the long run sets the ground for them to craft new options together (Adler, 2013). Forester (2013) explicates the reasons behind successful collaborative planning in such cases, and underlines how a planner can still act as 'facilitative leader' in finding the best solution for the public good. In these instances, planners feel less alienated since they incorporate the diverse priorities of the many stakeholders into the planning process.

However, the story for planners may be quite different when they are faced with political conditions in which they have no space to express their expert opinion, as is the case when political authorities and market forces dictate planning decisions (Tasan-Kok, 2012). Struggling between the global and local market conditions that dominate urban policy-making (Tasan-Kok, 2007), planners become alienated as they lose possibilities to collaborate with people, engage with the public good and promote socio-spatial justice. It is with this in mind that we investigate these cross pressures (Sager, 2009) from the perspective of young planners, defining clearly the feelings of alienation from the planning practice that they experience. Alienation is a broad concept that runs deep in a capitalist society. The concept is operationalized by Seeman (1959), who defined five dimensions of alienation, namely 'powerlessness, normlessness, meaninglessness, isolation and self-estrangement'. ${ }^{1}$ During our pilot research with Turkish planners we often came across these feelings that Seeman has linked to alienation in reference to the expression of disappointment. Accordingly, in our analysis we profited from this framework to operationalize the alienation concept and also to provide an analysis of the process of alienation of young planners.

We formulated the research around three main questions: (1) How do young planners feel when they face cross pressures that result from the conflicting theory and practice of their profession?; (2) To what extent do they feel alienated from planning practice due to these cross pressures? and (3) To what extent does their alienation induce characteristic behaviours, feelings and attitudes among these planners? To tackle these questions, the article draws upon a three-stage 'mixed-method research'. In the first stage, 100 randomly selected planners ${ }^{2}$ employed in diverse areas of practice completed questionnaires using Internet-based software. The questionnaires included very simple questions about their personal and professional background, as well as some open questions about their level of satisfaction with their education and practice, and the reasons behind any disappointments they may have. In the second stage, drawing upon the results of the questionnaires, we identified certain feelings related to alienation and formulated short semi-structured interviews with a few young planners to observe whether our argument of alienation matched their experiences. Finally, revising our questions to match these feelings, in the final stage we conducted semi-structured in-depth interviews with 20 young planners, who were selected based on a 'purposeful sampling method' and snowballing. The research was carried out between April 2014 and April 2015 through face-to-face or Skype meetings (as the respondents were located in different parts of the country). All of the participants had graduated after 2004, and almost all were at the time working in different public or private institutions (ministries, municipalities, planning, project development or real estate valuation companies and universities). We used the questionnaires first to see whether our argument (that they are disappointed with the practice) made sense, but more importantly, to underline the diverse categorizations of feelings that we later analysed through in-depth interviews. We transcribed and discourse analysed 
the interviews to identify traces of feelings connected to alienation, and to understand the coping mechanisms young planners have developed to overcome these feelings.

The next section explicates how entrepreneurial and authoritarian state interventions in urban development have been taking place in Turkey, while an idealistic planning education system has created unreasonable expectations from the practice for young planners. The third section reveals the planners' views on the future of planning practice, and highlights some relationships between these views and their profile in the light of the preliminary findings from the questionnaire. The fourth part focuses on the interview findings, and makes an in-depth analysis into the causes and consequences of the planners' alienation from work. The final part summarizes the main findings related to the coping mechanisms employed by planners and comments on how planning education, alternative ways of politicization and engaging with society can change the prospects for planners.

\section{Turkish planners under cross pressures between entrepreneurial and authoritarian government and idealistic education}

Planning education in Turkey, as in many other countries that follow the modernist planning tradition, is premised on the pursuit of the public good. Despite some differences between the curricula and approaches of different planning schools, students are taught theories, methodologies and cases for the production of ideal cities, following mainly urban design principles. All planning schools in the country devote the first two years of the four-year undergraduate programme to basic urban planning and design principles, where students exercise these principles in studio projects and learn how to produce urban space, considering spatial order and integration, accessibility and mobility, liveability and equal public services for all (Günay, 2012). They draw up schemes, diagrams and draft plans on core planning issues, deciding on land use, controlling density and sprawl, and enhancing public values and social well-being. The last two years of their education emphasize the spatial planning system, focusing on its legal aspects and its operation at different scales. Students develop future scenarios for cities on how to tackle uneven geographical development and how to meet sustainable development goals. Moreover, in planning studios, apply rational comprehensive, collaborative and strategic planning approaches are applied to specific cases, allowing them to grapple with complex social, economic and political problems. Although there are slight differences among different universities and departments, the common denominators are public good, democracy and participative decision-making in planning (Tekeli, 2007).

Planning educators in Turkey are aware of the contradiction between the idealistic values and the principles of education, on the one hand, and the market-dominated planning practice on the other, yet most believe that it is their mission to create ideal planners who lead collaborations between diverse stakeholders like an 'orchestra conductor' (Günay, 2012), and who inspire new ways of thinking and acting to serve the public good (Bademli, 2005; Keskinok, 2006).

Turkey's planning community, organized within the Chamber of City Planners, shares these views on the planning profession. In 2014, the Chamber issued a guideline for planning practice entitled 'ethical rules and principles for the planning profession' (see ŞPO, 2014). According to this document, planning practice is a strategic public service that considers the long-term well-being of society and preserves the natural and historical 
environment. Whether working in the public or private sector, planners ought to preserve the liveability, historical and cultural heritage, social diversity and publicness of the city (ŞPO, 2014). Owing to their comprehensive and multi-disciplinary approach, they ought to take a holistic perspective on the development of cities. For instance, a planner should not make partial plans or property-led urban projects without considering their social and spatial effects on the rest of the city. Although top-down state regulations and private sector interests exert pressure on the decision-makers, planners are supposed to maintain an occupational independence from political authorities and market forces in order to serve the public good (ŞPO, 2014).

These public-good-oriented values and principles are disseminated by planning educators and the planning community, engendering a shared identity and a sense of belonging among new graduates. Young planners derive from these values and principles the meaning of their profession, its public-good orientation and its collaborative role. However, political authorities and market forces exert an adverse influence on their perception of the planning profession and its practice. The roots of this influence date back to the 1980s when neoliberal policies started to dominate cities and planning. Since the 1980s, political authorities have prioritized supply-side and growth-oriented policies that attract private sector investment, the privatization of public resources and the stimulation of the construction sector, regardless of social and environmental costs (Keskinok, 2006; Şengül, 2009), while stimulating entrepreneurialism with outspoken propaganda about success based on private investments in mega projects.

The state has played a leading role in this process, especially after 2002 (when the AKP government came to political power), by enforcing new laws, reorganizing planning powers and instigating large-scale projects (Balaban, 2012; Eraydin, 2012). Through such top-down regulations and projects, the state has consolidated its control over the production of space (Kuyucu \& Ünsal, 2010; Penpecioglu, 2011). There are four main types of actions, as defined by Eraydin and Tasan-Kok (2013), that characterize the entrepreneurial and authoritarian state interventions from the early 2000s onwards: The 'gentrification' of central neighbourhoods through the changing of building rights and building codes for private property development; the designation of 'special project areas' to attract new functions on lands owned by public organizations for private business functions; 'largescale infrastructure projects' to attract new international and local enterprises, even when out of compliance with existing plans; and the designation of new sites for 'gated communities' to provide affluent groups and foreigners with a high-quality residential environment. In this process, new by-laws are enacted, and certain state organizations (like the Mass Housing Authority (TOKİ)) are given special legal powers that allow them to bypass local governments in the execution of these projects.

Moreover, the planning and implementation of mega projects, which are operationalized through partial plan revisions that bypass current long-term comprehensive-holistic plans, often leads to civil unrest as a result of the suppression of social responses against them (such as the Gezi protests). Projects like the 'Third Bridge' and 'Third Airport' in Istanbul $^{3}$ and the 'Presidential Palace' in Ankara ${ }^{4}$ have been hailed by the government as a sign of progress, and any social mobilization against them has been suppressed, sometimes aggressively, by the AKP administration (i.e. heightened police surveillance, use of physical force, the prosecution of professionals, and media and legal experts). This has discouraged organized social responses by instilling fear in society (Eraydin \& Tasan-Kok, 
2013; Şengül, 2015). People are prohibited from staging protests in public squares (like Taksim and Kizılay), and with the enactment of a new internal security bill, the government has authorized the police to imprison people to pre-empt urban social movements. Despite criticism and protests from the planning community, political authorities impose these projects and enforce project-based legal regulations to eliminate oppositional actors (for example the Chambers of Architectures and Planners, and environmentalist NGOs) and to block them from filing lawsuits against projects. In addition, the government has also dismantled certain public institutions (such as the Conservation Boards and District Municipalities) with oppositional leanings, and reallocated their planning powers to state institutions controlled by the ruling political party (Penpecioglu, 2012).

As summarized above, entrepreneurial and authoritarian rules and conduct interfere with the planning profession and its practices and mechanisms. While most of the projects mentioned above are managed according to project-based regulations, by-laws and partial plan revisions, comprehensive-master or strategic planning decisions of municipalities and democratic-participative planning procedures have been completely disregarded. Under such coercive and contradictory forms of entrepreneurial and authoritarian urban policies, it is not easy for planners to work according to the profession's goal of serving the public good, in that their work is subjected to the top-down decisions of the authoritarian government, and is isolated from its substance. In this contradictory socio-political environment, planners cannot free themselves from the cross pressures exerted by authoritarian state regulations and market forces, on the one hand, and idealistic planning education and the planning community, on the other. It is, in a way, quite normal to expect any young professional to become alienated from his/her work under such confusing conditions. The following section discusses the disappointment and frustration felt by the planners, based on the findings of the questionnaire.

\section{Turkish planners' disappointment in the planning profession: findings from the questionnaire}

The questionnaire was conducted with graduates of the City and Regional Planning departments of different universities, all of whom have different work profiles, but fairly evenly distributed. ${ }^{5}$ The survey was carried out on a random sampling of planners from different graduation years. The findings suggest that most of the young planners are not satisfied with working in planning practice. Only $12 \%$ of the respondents stated that they are 'satisfied working as a planner', while the remaining $88 \%$ claimed to be 'dissatisfied' and 'disappointed', 'frustrated' and 'unable to reach their expectations' working as planners, confirming our argument related to the general dissatisfaction in the field. The questionnaire findings revealed a relationship between work profile and satisfaction/dissatisfaction in work, with more than half of the public sector planners claiming to be dissatisfied with their work, in contrast to the lower numbers in the other sectors claiming a lack of job satisfaction. ${ }^{6}$ The underlying reason for this is that public sector planners are subjected more to pressures from authoritarian urban policies and topdown state regulations than the other work profile groups (interview findings reinforce this argument), and are also dissatisfied with the conditions (financial and emotional) under which they work. Almost half of the respondents (44\%) were pessimistic, and stated that it was doubtful whether the profession's ethical rules and principles could be 
applied in the planning profession in the future. These 'hopeless' planners responded to our open-ended questions by emphasizing that 'political and market forces dominate over planning practice' and that 'planners have become estranged from the idea of public good and social justice'. On the other side, $34 \%$ of respondents were 'optimistic' and maintained their belief in the ethical rules and principles of planning for the future. According to these 'hopeful' planners, the profession's public ideals, ethical rules and principles are still powerful enough to shape the future if planners organize and act with solidarity and initiate a bottom-up struggle against authoritarian neoliberal urban policies'. Only a small percentage of the respondents (13\%) stated that they 'no were longer concerned with the ideal of the public good in planning, nor its ideals or ethical principles'.

Not surprisingly, these views have changed over years. As Figure 1 illustrates, a relationship exists between graduation year and views on the future of the planning profession. Feelings of both pessimism and optimism were found to be common among the planners that graduated in the 2003-2011 period. The coexistence of these contrary attitudes among newly graduated planners could be attributed to the Gezi protests and accompanying rise of urban social movements, as underlined clearly by some of the respondents. Of the entire group, formerly graduated planners are more likely to give up these publicoriented ideals and principles. This 'unconcerned' behaviour was found to be most widespread among planners who had graduated before 2004 .

The survey also identifies a relationship between the work profiles of the planning graduates and their views on the future of the profession. It is obvious that planners working in the public and private sectors are more pessimistic than others, with more than half of the private and public sector planners saying that they are pessimistic about the future of the planning profession in Turkey, though the former is more pessimistic than the latter (Figure 2).

The questionnaire included an (optional) open-ended question on the reasons for their disappointment. In reply, some of the respondents spoke about their displeasure at the contradictions between planning education and practice. Their responses can be categorized under four groups: those who feel 'pressures from market forces' (34\%); those who

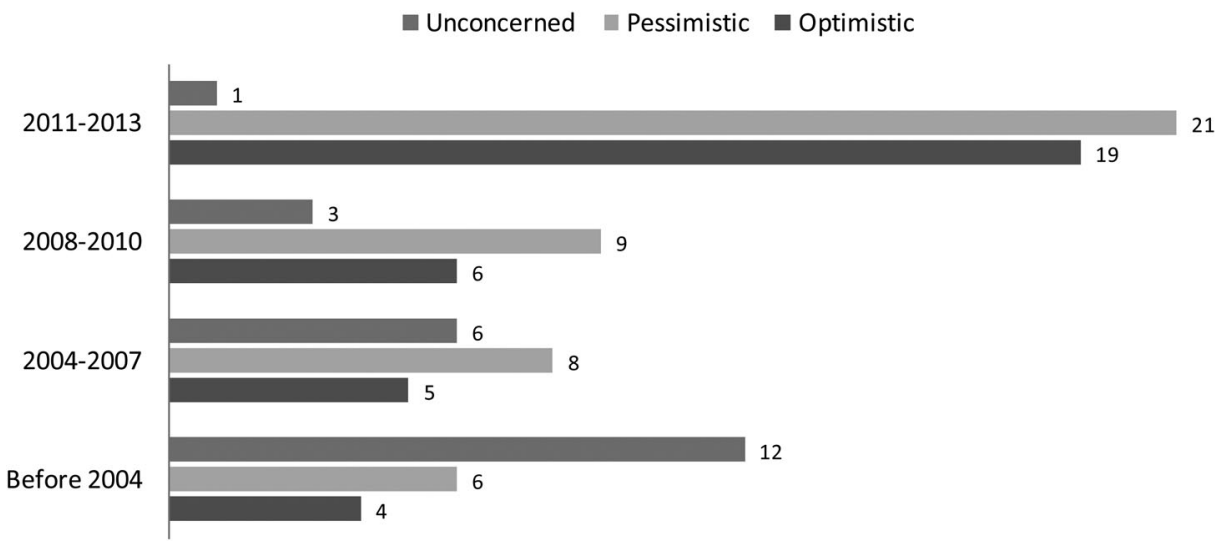

Figure 1. Views on future of planning profession according to graduation years (cross tabulation). Source: Authors. 


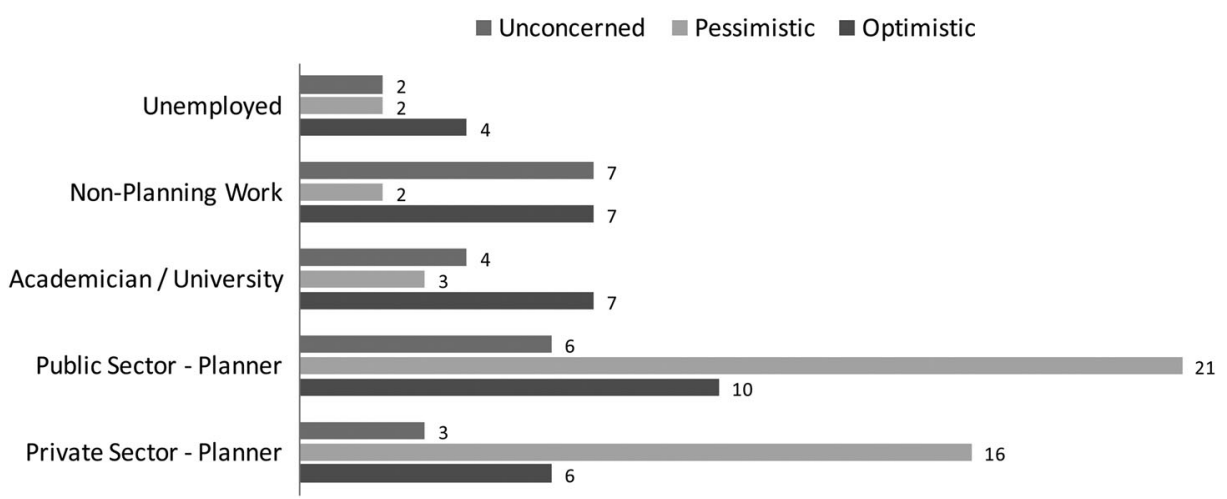

Figure 2. Views on future of planning profession according to work profiles (cross tabulation). Source: Authors.

indicated the influence of 'authoritarian and top-down state regulations' (32\%); those who emphasized the 'inadequacies of planning education' (21\%) and those who were uncomfortable with the 'unethical attitudes of colleague planners' (13\%). These contradictions are a good match with the current problems being faced by the planning system in Turkey. It was noted further that the responses differed according to graduation years, indicating that planners started to observe the dominant profit-oriented motives of the stakeholders, the authoritarian impositions of politicians and the unethical practices of some planning practitioners as they gained more experience in practice. As insiders of the planning system, they are able to observe these actors and experiences closely, and can see how they reproduce an authoritarian system and market-dominated planning practice. The result for most of them manifests in feelings of 'frustration' and 'irritation'.

Furthermore, the planners' views on the current problems in the planning system differ according to their work profiles. Most (76\%) of the private sector planners specified 'pressures from market forces' and 'inadequacies of planning education' as the reasons underlying their feelings of disappointment and frustration, having to work under market pressures and feeling that they are ill-equipped to do so. In contrast, public sector planners (84\%) emphasized 'authoritarian and top-down state regulations as well as pressures from market forces' (Figure 3) as the leading reasons for their disenchantment with the profession, although they feel the market pressure from a different angle to the private sector planners. Most of these planners work in ministries and municipalities, and so are well positioned to observe the roles of politicians and high-level bureaucrats. In this regard, they point out overwhelmingly political decision-makers as the leading cause of socio-political problems, who they see as creating deep contradictions and challenging the public orientation of the planning profession (an in-depth analysis of the views of these planners is made in the following section).

The findings of the survey constitute the empirical evidence for the first stage of our research, which aims to understand whether or not young planners are disappointed with their practice, as we argued at the outset. Our findings reveal two important relationships between the profile on planners and their behavioural tendencies. First, the rates of feeling 'pessimistic' and 'optimistic' are higher among young planners; while old/experienced planners tend to position themselves as 'unconcerned', showing that their idealism 


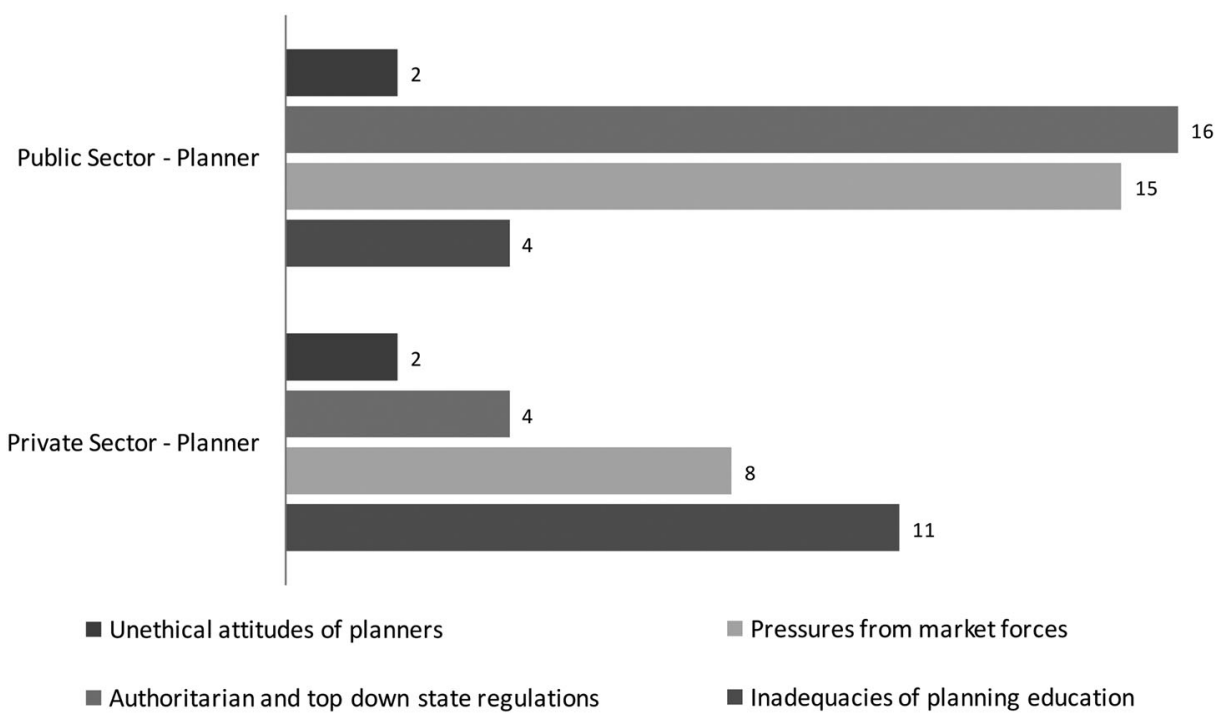

Figure 3. Public and private sector planners' views on current problems in the planning system (cross tabulation). Source: Authors.

has waned over the years. The young planners' feelings can be classified as either 'pessimistic' or 'optimistic', which merits the more in-depth analysis provided in the following stage of our research. Second, although all of the planners function under market and political forces, they perceive conditions differently and see pressures from different angles. As planners gain experience in municipalities, ministries or private companies, they are better able to observe the dominant role of the political and market actors in practice than those who work in the academy, in sectors other than planning, or those who are unemployed. These two main findings garnered from the questionnaire led us to concentrate on young planners who had graduated after 2004 and who had work experience in the public or private sector for in-depth interviews. The next section reveals how the different behavioural tendencies of young planners have been shaped in relation to their alienation, drawing upon the interview findings related to their alienation from the planning profession.

\section{Young planners' alienation from authoritarian state-regulated urban development: findings from the in-depth interviews}

This section explores the reasons behind and consequences of the diverse behaviours of planners by analysing the evidence garnered during the in-depth interviews. As mentioned in the introduction, young planners were selected for interviews after a number of indepth open-ended discussions with several young planners as a pilot study to test the research questions. Since our questionnaires had brought us into contact with them, and the survey had been very positively perceived by the young planners, we found it appropriate to use these contacts for the selection of interviewees. At the outset, we selected five planners who were eager to be involved in the interviews, and during the interviews they gave us the names of the other young planners who may be willing to 
be interviewed. The interviews continued as a result of this 'snowball sampling process', which in the end led to interviews with 20 young planners. ${ }^{7}$

The young planners involved in this stage of the study are graduates of the planning departments of three different universities: Middle East Technical University in Ankara; Mimar Sinan Fine Arts University in Istanbul and Dokuz Eylül University in Izmir. Most of the respondents have continued working in the same city in which they had graduated, and only three of them are unemployed and looking for work. The respondents are employed in diverse fields, including urban regeneration and urban design, tourism planning and conservation, real estate valuation, development planning and urban project management, etc. (detailed information on interviewees is provided at the end of article under 'Interviewee List'). The in-depth interviews can be considered limited as a result of this non-random sampling of young planners.

As the first dimension of alienation, the young planners feel 'powerless' in planning practice, working under top-down regulations that interfere with local decisions based on their expertise. One public sector planner who has been working in a ministry for six years explains her feelings of powerlessness: 'I cannot imagine planners as decisionmaking actors ... We are obliged to implement imposed decisions that were taken by powerful people' (Interviewee, 15). Another public sector planner working as the head of a planning department in Istanbul Greater Municipality confesses that 'planners in the municipality would not think of opposing large-scale projects like the Third Bridge or the Third Airport' (Interviewee 16). The views of the private sector planners is not so different, with three of them speaking of feelings of powerlessness during the interviews, knowing that existing plans can be easily revised with top-down interventions for projects that are imposed by powerful political and economic interests (Interviewees, 2, 4 and 7). In brief, planners see themselves as powerless, being expected to simply obey the top-down regulations when making plan revisions. However, there are also provoked planners most of whom work in public institutions and universities, who, to overcome this sense of powerlessness, treat planning practice as an arena of social struggle against market domination and authoritarian state regulation.

I have not lost my belief in the profession, but I know the reality. I see these bad practices in planning as a field of struggle, and I believe it is my duty to defend the ethical rules and principles of the planning profession. We should make these public principles dominant over planning practice, but we know very well that such efforts entail a social struggle. (Interviewee 5)

Another group of planners who are keen to develop their careers in the private sector turn to profit to get their share from the existing planning system, being entrepreneurial and utilitarian, aiming to develop their own businesses in line with the logic of neoliberalization (for instance, Interviewees 7, 13 and 19 could be defined within this profile). It is also possible to observe such planners in key decision-making positions in public sector institutions (for instance, Interviewee 16). From their perspective, the level of a planner's success should be measured by the amount of work they do and the money they accumulate (Interviewees 7 and 13). This instrumental attitude leaves no room for social objectives and reflects how young planners have become estranged from the ideals of planning of collaborative-participative procedural priority and public-good principles. 
As another dimension of alienation, planners experience 'isolation' not only in planning practice, but also in their relations with society. If their ideals, values and thoughts differ from the dominant political and economic interests, they start to feel isolated over time. Planners working in the public sector are particularly prone to this isolation problem, and interviewees 3,10,12, 14 and 18 underlined this feeling explicitly. Some of them response isolation without questioning the powerful interests, existing rules or regulations and follow procedures, apply laws and revise plans as requested; while others may resist such interventions by refusing to give their approval to projects, interventions and development plan revisions; however, there is a cost to this resistance, as one of the planners emphasizes, 'if we do not develop solidarity and organisation on the basis of our public-good oriented ideals, we face serious pressures from senior managers in the form of intimidation and all sorts of exclusion' (Interviewee 18).

Planners also feel isolated in a wider social setting, which can lead to a strong sense of pessimism. Disappointed and frustrated planners of different ages and with different work profiles state a common perception that their values, principles and ideals are somewhat different from what is expected of them in society (Interviewees 2, 6 and 17). For these planners, 'the Gezi protests and urban social movements were not a breakthrough in overcoming their isolation from society' (Interviewee 10). They point out how Istanbul's northern forests and the Atatürk Forest Farm in Ankara are plundered, despite the scientific critiques, court decisions and rising opposition from different parts of civil society. These respondents appear to become very pessimistic in the early years of their career, while more experience planners have become unconcerned over time after facing similar issues over and over again.

On the other side, some young planners remain hopeful for the future, and pledge to fight for the ethical principles of planning and for the removal the political barriers that cause their isolation. The interviews reveal that most of these young hopeful planners work in public institutions or universities, and are involved in the activities of the Chamber of City Planners. Most of them have left-wing political views, and see it as their professional responsibility to explain to people how the prevailing planning practices lead to social, spatial and ecological problems (for instance, Interviewees 4, 5, 8, 12, 14 and 18). Accordingly, they seek to raise public awareness on the real causes of urban conflict and injustice, and see urban social movements as a revolutionary path towards engagement with society; as transformative socio-political sites of public communication; as an opportunity for collaborative learning; and as a means of struggling together against authoritarian neoliberal urban policies. The Gezi protests and the rise of bottom-up initiatives and neighbourhood forums are all very important to these planners, whose ambition is to increase their collaboration with such movements in their struggles against capitalist urbanization.

We need to explain urban conflicts, inequalities and injustices to society ... We can no longer maintain isolated technocratic positions. We ought to change our behaviour and we need to develop organic and constructive relations with society. We need a bottom-up socio-political struggle. The Gezi resistance showed that this was possible ... We have to collaborate with all parts of society in this struggle. (Interviewee 14)

In line with some of the other feelings defined by Seeman (1959) related to alienation, planners feel 'meaningless' and 'normless', and are losing sight of the profession's long- 
term social purposes and public-oriented ideals. Market forces and political authorities expect planners to operate as mere technicians, insisting that they apply rules and regulations without question, which has led young planners with different work profiles to state that planning practice is becoming an instrumental job, a mechanical and routine one in which long-term public priorities are ignored and violations of ethical rules and principles are commonplace (Interviewees 4, 11, 12 and 20). A young planner with just one year of experience in a private planning company (working on urban regeneration projects in Istanbul) recounts that they conduct surveys to understand people's expectations with respect to living in regeneration areas, but complains that the planning and construction companies disregard these surveys: 'The only things they consider are the highest density for construction and the maximum profit they can make from urban regeneration' (Interviewee 11).

Others criticize the way private planning companies operate, indicating that company owners make decisions in line with the expectations of political authorities and property owners, and underline that company owners expect planners to draw up already taken decisions without question (Interviewees 1, 19 and 20). One of these three planners expresses that she felt 'irritated at having to work like this and left the company with huge disappointment', and later started working as an academician in a university (Interviewee 20). Others have also left their positions in planning practice and have changed their fields of specialization, working instead in urban design and project management (Interviewees 1 and 20). As planning practices are a source of significant disappointment among planners, they often leave their planning careers behind in time to work in different fields (academia, urban design, project management, etc.).

There are also other young planners who have not found the opportunity to change their jobs. One of these started working in a public institution with idealistic expectations, but saw later that the 'public institution's main task is to privatise public lands for the construction of shopping malls and tourism investments' (Interviewee 10). She goes on to say 'they command planners with a chain of impositions that come from the general directorate at the top and the chief officer at the bottom of the hierarchy. If planners do not obey such instructions, they face forms of oppression that make them feel isolated and excluded. In this regard, planners feel like they are subjected to pressure not only from government's entrepreneurial policies, but also from its authoritarian power and top-down impositions. Given these deep contradictions and authoritarian regulations, planners feel compelled to engage in meaningless and normless behaviour. The head of a planning department of Istanbul Greater Municipality confesses that 'planners in the municipality know that the third bridge and airport projects are not coherent with Istanbul's master plan' (Interviewee 16) and planners working this department are now making partial revisions to the master and development plans to legalize these projects. Another planner that has been working in the Ministry of Environment and Urbanism for four years explains in brief why she feels meaningless and normless.

Our work here is to carry out implementations on the basis of laws and legislative frameworks; but we do not take planning decisions in this work... We cannot decide on where reserve areas and urban regeneration sites should be; these are decided by the cabinet, and you cannot see a powerful professional justification behind these decisions ... Actually, they use us as their instruments. (Interviewee 3) 
Not all of the planners feel disappointed, as some respond differently to the feelings of meaninglessness and normlessness. These planners have business-oriented perspectives, and gain private sector experience after their graduation by working in urban regeneration, urban design, real estate valuation and construction businesses, after which they aim to establish their own companies to make money in these fields of work. Over time, these planners drop the public priorities, ethical norms and principles they learned and conform to the dominant planning system, aiming to gain more profit and power (Interviewees 7, 13 and 19). As one such planner says, 'the public-good idea and planning principles we were taught in school are totally irrelevant in the existing planning system' (Interviewee 7). These ambitious profit-oriented planners learn in practice very well how to generate business and profit within the existing planning system. Rather than pursuing the long-term social objectives of planning, they concentrate on establishing their own businesses with high-profit expectations. Instead of striving for quality, they are concerned with quantity and bringing in business, and the key to becoming an 'entrepreneurial' and 'successful' planner is 'profit making', as interviewee 13 reveals:

In the future I am planning to take some steps to increase my capital accumulation. There are over 10 stages in urban regeneration works, including surveys, site analyses, feasibility studies, development plans, architectural and urban design, construction, and so on. I think that I can incorporate all of these activities into one business and make huge profits with my new company. (Interviewee 13)

Young planners also experience self-estrangement, as another feeling connected to alienation: 'losing the idea of intrinsically meaningful activity' (Seeman, 1959, p. 790). We argue that Turkey's disappointed young planners do not see planning practice as a meaningful activity in terms of the public good and social justice, and cannot perceive the profession as an ideal career because they cannot implement its public-oriented priorities and principles. In practice, planning is seen as an ordinary job leading to a stable income. In the workplace, they feel bored, unhappy, dissatisfied and meaningless (Interviewees 6, 11 and 15). Most agree that if they could find a better job that would make them happier and more creative and meaningful to society, they would take it up without hesitation (Interviewees 2, 3, 10 and 15).

Some respondents decided to pursue a master's or Ph.D. degree in planning because, in their view, academic study is a creative platform for thinking about and acting on planning's ideals in such idealistic projects related to resilient planning, low-carbon urbanism and participative local governance models. By formulating ideas, conducting research and developing models, they would feel creative and meaningful, and would be working for the future of cities and planning (Interviewees 10, 15 and 18). It is for this reason that most of these Ph.D. candidates consider switching to an academic career after completing their degree.

While the disappointed and business-oriented planners cited above have serious selfestrangement problems, the politicized planners are less troubled. In the early years of their career, most of them start to work in public institutions with idealistic intentions, but after a few years they realize that putting the public-oriented principles of the profession into practice in these institutions is not possible. Rather, they reflect these ideal public values and principles in universities, Chamber of City Planners, urban movements, neighbourhood forums, etc. After gaining a few years of experience in planning practice, 
they take an active role in such sites of socialization where they find hope, meaning, dignity and a social role (For instance, Interviewees 12, 14, 18 and 20).

It is not possible to apply public-oriented ideals in planning practice. The only places in which I can work with these ideals are universities, Chambers of City Planners and local initiatives. That is why I am so active in these platforms ... Eventually, all people strive to find a channel to engage with society. I found my channel in this way. (Interviewee 20)

The different responses to questions on the dimensions of alienation should not be understood as fixed attitudes, in that they are rather flexible, transitional and can change over time. For instance, the interview findings reveal how young planners that started work with full idealistic motivations have become disappointed as the years pass. Some respondents emphasized clearly their lack of motivation in resisting market domination and authoritarian state regulation in planning (Interviewees 3 and 10). The background of on disappointed planner is particularly dramatic:

I resisted the unethical planning practices in this public institution, but later I saw that I was alone in this struggle... I was exposed to serious oppression by the high-level decision makers ... After all this, I feel exhausted and I do not think I can keep up the struggle. (Interviewee 17)

However, this is only one side of the story, as some planners who start to work without questioning existing planning practices change their thoughts over the following years. A young planner explains the change in his own attitude:

I was disappointed when I first realised the power of politicians and investors in my first work experience ... but then these experiences lead me to raise my consciousness and I decided to join the struggle by involving myself in the Chamber of City Planners and urban movements. (Interviewee 4)

In the light of this empirical evidence, we advance our argument on alienation with three new dimensions that explain the feelings of practicing young planners as a response to the increasingly entrepreneurial and authoritarian state intervention. First, it is apparent that the cross pressures coming from market forces and authoritarian state regulation, the planning community and educators not only alienate planners from the profession of planning, but may also provoke them to become responsive, and even politicized, and to take part in urban movements on a voluntary basis. Second, disenchanted planners may conceal their alienation by burying it in an economic rationalization of planning practices. Finally, young planners may cope with alienation by resisting market-dominated, authoritarian state-regulated urban policies. The Conclusion section explains these arguments further and makes some comments on the future of planners in Turkey.

\section{Conclusion}

Planners in Turkey are educated with the ideal view to becoming powerful 'orchestra conductors' who are concerned with social priorities and have the ability to come up with solutions for the public good. Equity, justice, collaboration and participation are central to planning education in Turkey; and with these public values, planners are expected to work towards the well-being of society. However, this meaning and social responsibility come to be challenged by political and economic forces. Authoritarian and neoliberal 
urban policies instrumentalize planning practice, prioritize profit-oriented projects over long-term master plans, and impose legislation or use other forms of coercion to eliminate those who act in opposition, and their urban movements, protests and lawsuits. Under these authoritarian policies, it is not easy for Turkish planners to uphold the public-interest orientation of the profession and pursue its collaborative/participative aims, in that their work is subservient to authoritarian neoliberal top-down impositions (laws, projects, development plan revisions, etc.). They feel what Sager (2009) calls the 'cross pressures' of, on the one hand, authoritarian neoliberal urban policies, and on the other, planning educators and the planning community. As a result, they feel disappointment and become disengaged from the principles and ideals they acquired during their education.

Our research reveals that planners feel alienated from planning practice in several ways when they face interventions into their work and expert decisions. Turkey is an example of a political climate in which entrepreneurial and authoritarian interventions of the state are dominant. As our survey findings show, behavioural responses to alienation differ according to the work profile and graduation years of the respondent planners, and having confirmed the presence of a pattern of alienation, we concentrated our in-depth analysis on young planners who had graduated after 2004 and who had gained work experience in public or private sector institutions. Our intention in this regard is to understand their feelings and how they respond to alienation.

Our research shows that the young planners developed diverse feelings that confirm the alienation argument (powerlessness, normlessness, meaninglessness, isolation and selfestrangement). In search for an answer to our question on characteristic behaviours, feelings and attitudes among the planners, we revealed three behavioural tendencies that are widespread among planners. First, there are the 'lost planners' who are the most disappointed, who are dissatisfied working in planning practice and who have lost their belief in the profession, being always demotivated and frustrated. Almost all of them think about leaving their planning career behind and finding another job where they can feel happy and make a positive contribution to society. They tend to look outside their work for ways of feeling meaningful and beneficial to society. Second, there are 'profiteer planners' who play a conformist and opportunist role, conforming to the existing planning system and focusing on garnering more business and money from the system. They embrace the economic rationalization of an instrumentalized planning practice by maximizing their work and minimizing the time spent on tasks, such as development plans and their revisions, urban regeneration projects and real estate valuations. In this way, as pragmatic and entrepreneurial actors in neoliberal times, they mask the problem of meaninglessness by adopting a capitalist mentality (Gorz, 1989). The categories of lost and profiteering planners reflect how young people who have been educated to become powerful social actors turn out to be 'fallen public figures'.

The third behavioural tendency reveals another side to this story, in that the research has revealed the presence of 'struggling planners' who resist the market domination of the profession and its subservience to authoritarian state regulations. Most of these planners are politicized on the left and put emphasis on solidarity and urban movements to change planning practices in Turkey, and develop alternative means of furthering the public good. To this end, they are actively involved in the Chamber of City Planners and urban movements, where they play a revolutionary 'organic intellectual' role (Gramsci, 1971), and develop organic relationships among the different parts of political and civil society 
(state institutions, universities, media institutions, non-governmental organizations, urban movements, bottom-up initiatives, etc.). They deal with the feelings of alienation by perceiving themselves as working towards the public good by finding new ways of engaging with society, providing them with a sense of hope and meaning in their profession. Unlike the lost and profiteering planners, struggling planners represent 'rising public figures', since they strive to realize planning's public-oriented ideals and principles.

Of course, it is not suggested that these three categories reflect the fixed and stable behavioural tendencies of planners. The attitudes of planners can change over time and transitions between different categories are possible, with transitions between the lost and struggling categories revealed in the survey. Young planners who start work with a tendency to struggle for their principles turn out to be lost planners in the following years; just as lost planners who experience deep disappointment in the first few years of their careers develop a change in attitude in later years and start struggling against authoritarian neoliberal urban policies. Profiteer planners fall into a relatively isolated category that is closed to transitions from the other two groups. It is worth noting that changes in behavioural tendencies are often associated with changes in careers.

Alienation is ingrained in capitalist societies and cannot be overcome without changing the political-economic system. We acknowledge that the problem of alienation among planners cannot be resolved in a capitalist society; however, identifying alternative ways of engaging with society may alleviate it (Fisher, 2012). In this respect, future studies could explore how planning education, new directions for socio-political struggle and collaboration may change planning practice in Turkey. We conclude this study by offering some preliminary guidance for addressing this challenging question. First, as planning educators, we should imbue our undergraduates with a critical analytical approach so they can grasp how political power shapes the urban context. Planning academicians and the planning community carry the responsibility of introducing young professionals to alternative roles and methodologies that may inspire them to explore new ways of giving the public good precedence in planning practice. Even when under pressure from authoritarian neoliberal urban policies, young planners should not isolate themselves from ongoing urban socio-political struggles; but rather should raise awareness and rally support in line with their public-oriented principles. Developing organic relations between the planning community and urban social movements could be a fruitful starting point in this regard. Inspiration can be drawn from the experiences of planners involved in the struggle, their collaboration with urban movements and their efforts against authoritarian political forces. Young planners in Turkey should be encouraged to learn from urban social movements, as by establishing creative and organic relations with such movements, these young planners can take their destiny into their own hands and translate their priorities into new public-oriented planning visions and practices.

\section{Notes}

1. People feel 'powerless' when they believe that most of what happens to them is a result of things over which they have no control. As their powerlessness increases, they start to lose contact with their own labour (Erikson, 1986). This leads to 'meaninglessness', as people become unsure about what they ought to believe. People who suffer from meaninglessness may also relinquish commonly held standards and norms, leading to 'normlessness', which is a widespread problem 
in modern capitalist societies. Their attitudes become individualistic, instrumental and manipulative (Gorz, 1989). People live in an isolated manner and feel lonely in this increasingly individualistic and competitive system. 'Isolation' embraces such socio-political problems as weak solidarity and the loss of belief in collectivization-organization. 'Self-estranged' people depend on rewards that lie outside the activity itself: a doctor working merely for his salary or a clerk working only for a stable income. It is only outside work that such people can find meaning and social belonging (Harvey, 2015).

2. The total number of planners who started working and registered to Turkish Chamber of City Planners is 5.503 , and $43 \%$ of those falls into our young category meaning that they graduated after 2004 (ŞPO, 2015).

3. Third Bridge and Third Airport, under construction in the north of Istanbul, attracted serious criticism and controversy due to the presence of ecologically sensitive forests and water reservoirs in the northern part of the city (ŞPO, 2010). Experts point out that since the projects started, they have led to the felling of 245,000 trees, and that their destructive effects will continue into drinking water resources, forests and endemic plants (Tümerdem, 2014).

4. Constructed as the new seat of the President of Republic of Turkey, despite the presence of an existing historical and perfectly functional presidential palace. This is the most controversial project, covering approximately 30 hectares of land in the Atatürk Forest Farm (AOÇ), which was a protected green zone that was opened to development with an exception to existing legal regulations. A government decision is taken on the use of AOÇ land, and this exceptional law paved the way for the project (Candan, 2015).

5. The study group comprised $37 \%$ public sector planners, $25 \%$ private sector planners, $16 \%$ working outside the planning sector, $14 \%$ working in academia and $8 \%$ unemployed.

6. Of the total, $36 \%$ of private sector planners, $31 \%$ of people working outside the planning sector and $14 \%$ of the academicians indicated dissatisfaction.

7. All of the interviewees were in the 'young category' (graduated after 2004), and the majority had work experience in the public or private sectors (eight public sector planners, six private sector planners, three unemployed, two academicians and one working in Chamber of City Planners).

\section{Disclosure statement}

No potential conflict of interest was reported by the authors.

\section{Interviewee list}

No. 1 Working at an urban project development company; three years' experience

No. 2 Working at İller Bankası A.Ş. (a development and investment bank with the status of specialbudget joint-stock company); four years' experience

No. 3 Working at the Ministry of Environment and Urbanism; four years' experience

No. 4 Working at Kadıköy Municipality, previously worked at a planning company; ten years' experience

No. 5 Working in a public university as a research assistant, board member of the Ankara Branch of the Chamber of City Planners; six years' experience

No. 6 Unemployed, master student, worked previously for a real estate valuation company; two years' experience

No. 7 Working as a manager in a real estate valuation company; six years' experience

No. 8 Working at the Ankara Branch of the Chamber of City Planners; two years' experience

No. 9 Unemployed, master student, worked previously as an instructor; four years' experience

No. 10 Working at the Privatization Administration; four years' experience

No. 11 Unemployed, worked previously at a construction company; one year's experience

No. 12 Working at Izmir Greater Municipality; three years' experience

No. 13 Planning company owner, worked previously for planning companies; four years' experience

No. 14 Working at Ministry of Culture and Tourism; four years' experience

No. 15 Working at Ministry of Food, Agriculture and Livestock; six years' experience

No. 16 Head of a Planning Department at Istanbul Greater Municipality; ten years' experience 
No. 17 Working at the Cultural and Natural Heritage Preservation Board; nine years' experience

No. 18 Working at the Cultural and Natural Heritage Preservation Board; seven years' experience

No. 19 Urban design company owner, worked previously for a planning company; five years' experience

No. 20 Working at a public university as a research assistant, board member of the Ankara Branch of the Chamber of City Planners, worked previously at a planning company; five years' experience

\section{Acknowledgements}

The research was funded by TÜBİTAK (Scientific and Technological Research Council of Turkey) within the International Postdoctoral Research Fellowship Programme (2219). The publication of this article was also financially supported by TUDelft, Faculty of Architecture and the Built Environment, Department OTB for the Built Environment where both authors were affiliated during this study. The authors are grateful for both organizations for supporting this research. Any opinions expressed in this paper are, of course, solely the author's own.

\section{References}

Adler, P. (2013). Dispute resolution meets policy analysis: Native gathering rights on private lands. In J. Forester (Ed.), Planning in the face of power (pp. 41-57). Washington, DC: American Planning Association Press.

Albrechts, L. (2004). Strategic (spatial) planning reexamined. Environment and Planning B: Planning and Design, 31(5), 743-758. doi:10.1068/b3065

Bademli, R. (2005). Kentsel Planlama İșliği Notları, TMMOB SPO Yayınları.

Balaban, O. (2012). The negative effects of construction boom on urban planning and environment in Turkey: Unraveling the role of the public sector. Habitat International, 36(1), 26-35. doi:10. 1016/j.habitatint.2011.05.003

Blechman, F. (2013). From conflict generation to consensus building: Using many of the same skills. In J. Forester (Ed.), Planning in the face of power (pp. 23-36). Washington, DC: American Planning Association Press.

Candan, T. K. (2015). Cumhuriyetle Hesaplaşmanın Zirve Mekanı: Atatürk Orman Çiftliği ve Kaçak Saray, Dosya, TMMOB Mimarlar Odası Ankara Şubesi.

Eraydin, A. (2012). Contradictions in the neoliberal policy instruments: What is the stance of the state? In T. Tasan-Kok, \& G. Beaten (Eds.), Contradictions of neoliberal planning: Cities, policies and politics (pp. 61-79). Dordrecht: Springer.

Eraydın, A., \& Tasan-Kok, T. (2013). State response to contemporary urban movements in Turkey: A critical overview of state entrepreneurialism and authoritarian interventions. Antipode, 46(1), 110-129. doi:10.1111/anti.12042

Erikson, K. (1986). On work and alienation. American Sociological Review, 51(1), 1-8. doi:10.2307/ 2095474

Fisher, R. (2012). Fifty theses on urban planning and urban planners. Journal of Planning Education and Research, 32(1), 107-114. doi:10.1177/0739456X11420441

Forester, J. (1989). Planning in the face of power. Berkeley: University of California Press.

Forester, J. (2013). Planning in the face of conflict: The surprising possibilities of facilitative leadership. Chicago, IL: APA.

Gorz, A. (1989). The critique of economic reason. London: Verso Books.

Gramsci, A. (1971). Selections from the prison notebooks. New York, NY: International Publishers.

Günay, B. (2012). Planlama Kuramı ve Kentsel Planlama Eğitimi. (Melih Ersoy, der.). Kentsel Planlama Kuramları. Ankara: İmge.

Harvey, D. (2015). Seventeen contradictions and the end of capitalism. Oxford: Oxford University Press.

Healey, P. (1996). The communicative turn in planning theory and its implications for spatial strategy formations. Environment and Planning B: Planning and Design, 23(2), 217-234. doi:10.1068/ b230217 
Keskinok, Ç. (2006). Kentleşme Siyasaları. Ankara: Kaynak Yayınları.

Kuyucu, T., \& Ünsal, Ö. (2010). Urban transformation as state-led property transfer: An analysis of two cases of urban renewal in Istanbul. Urban Studies, 47(7), 1479-1499. doi:10.1177/ 0042098009353629

Penpecioglu, M. (2011). Kapitalist Kentleşme Dinamiklerinin Türkiye'deki Son 10 Yılı: Yapılı Çevre Üretimi, Devlet ve Büyük Ölçekli Kentsel Projeler [Last ten years of capitalist urbanization dynamics in Turkey: Production of the built environment, state and large-scale urban projects] Birikim, no: 270.

Penpecioglu, M. (2012). Political construction of urban development projects: The case of Turkey (Unpublished PhD Thesis). Middle East Technical University, Ankara.

Sager, T. (2005). Communicative planners as Naïve Mandarins of the neo-liberal state? European Journal of Spatial Development. Retrieved from http://www.nordregio.se/Global/EJSD/Debate/ debate051208.pdf

Sager, T. (2009). Planners' role: Torn between dialogical ideals and neoliberal realities. European Planning Studies, 17(1), 65-84. doi:10.1080/09654310802513948

Seeman, M. (1959). On the meaning of alienation. American Sociological Review, 24, 783-791. doi: $10.2307 / 2088565$

Şengül, H. T. (2009). Kentsel Çelişki ve Siyaset: Kapitalist kentleşme süreçlerinin eleştirisi. Ankara: İmge.

Şengül, H. T. (2015). Gezi Başkaldırısı Ertesinde Kent Mekanı ve Siyasal Alanın Yeni Dinamikleri. METU Journal of Faculty of Architecture, 32(1), 1-20. doi:10.4305/METU.JFA.2015.1.1

Sherman, L. (2013). Mediation and collaboration in architecture and community planning. In J. Forester (Ed.), Planning in the face of power. (pp. 3-19). Washington, DC: American Planning Association Press.

ŞPO. (2010). 3. Köprü Projesi Değerlendirme Raporu [Evaluation Report on Third Bridge Project]. Retrieved from http://www.spoist.org/dokuman/Raporlarimiz/spoist_3.koprurapor.pdf

ŞPO. (2014). Mesleki Etik ve İlkeler [Ethical rules and principles prepared for the planning profession]. Retrieved from http://www.spo.org.tr/genel/bizden_detay.php?kod=4143\#. Ur8CLvRdWSo

ŞPO. (2015). Quantitative data received from chamber of city planners in Turkey (The number of city planners and their years of graduation). Retrieved from http://www.spo.org.tr/ hakkimizda/istatistikler/rapor1.php

Tasan-Kok, T. (2004). Budapest, Istanbul, and Warsaw: Institutional and spatial change. Eburon: Delft.

Tasan-Kok, T. (2007). Global urban forms and local strategies of property market actors. Journal of Housing and the Built Environment, 22(1), 69-90. doi:10.1007/s10901-006-9067-0

Tasan-Kok, T. (2012). Introduction: Contradictions of neoliberal urban planning. In T. Tasan-Kok, \& G. Baeten (Eds.), Contradictions of neoliberal planning: Cities, policies, politics (pp. 1-18). Dordrecht: Springer.

Tekeli, İ. (2007). Akılcı Planlamadan Bir Demokrasi Projesi Olarak Planlamaya (İlhan Tekeli Toplu Eserler 7), Tarih Vakfi Yurt Yayınları.

Tümerdem, N. (2014). A case study of the third bridge: An exploration of the impacts of the transportation infrastructure on the city's geography. Paper presented at EURAU 2014, Istanbul. 